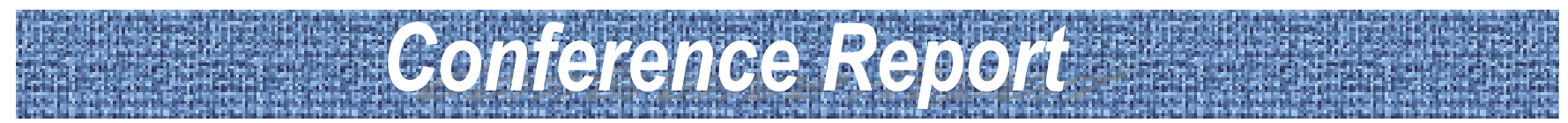

学界情報 国際会議レポート

\title{
4th IEEE International Future Energy Electronics Conference (IFEEC 2019) November $25-28,2019$, Singapore
}

2019 年 11 月 25 日から 28 日にかけて, シンガポールの Parkroyal on Beach Road にて 4th IEEE International Future Energy Electronics Conference (IFEEC 2019) が開催された。 IFEEC は，これまで台湾で開催されてきたパワーエレクト ロニクスに関する国際会議で, 世界中の学者, 学生, 研究 者および技術者を集めて, 将来のエネルギー応用のための 電子技術に関して 2013 年から 2 年に 1 度開催されている。 第 1 回から第 3 回は, 台湾で開催されており, 第 4 回とな った今回の IFEEC が，初めて台湾外で開催された。11月の シンガポールは, 気温が $25 \sim 31^{\circ} \mathrm{C}$ で降水量も非常に多く, 蒸し暑く感じる気候であった。11 月末でクリスマスが近か つたからか, 会場の Parkroyal on Beach Road 内のクリスマ スコーナーに IFEEC の案内板が立てられていた（図 1)。

会議初日の 25 日には，4 件のチュートリアルおよび Welcome Reception が行われた。Welcome Reception は，屋外 を予定されていたが雨が降る可能性があり, 会議会場の口 ビーにて立食形式で行われた（図 2)。Welcome Reception 終 了後には，当初予定されていた会場で夜景が見れるとのア ナウンスがあり，シンガポールの夜景を楽しむことができ た（図 3)。

会議 2 日目の 26 日には, オープニングセレモニー, プレ ナリーセッション, ポスターセッション, テクニカルセッ ションおよび Social Dinner が行われた。26日のプレナリー セッションでは, 赤木泰文先生, Prof. Gyu-Ha Choe (韓国), Prof. Mark Dehong Xu（中国）の3 名の講演が行われた。ポ スターセッション会場は, 昼食と同じ時間に別の会場で行 われたためかポスターセッションの聴講者が少なく感じ た。ポスターセッションでは, 30 件, ならびにテクニカル セッションは, 合計 11 セッションあり 79 件の発表が行わ れた。

会議 3 日目の 27 日には, オープニングセレモニー, プレ ナリーセッション, ポスターセッション, テクニカルセッ ションおよび Banquet が行われた。27 日のプレナリーセッ ションでは, Prof. Dushan Boroyevich (USA), 伊東淳一先生, Prof. Edward Yi Chang Senior（台湾), Prof. Jinjun Liu（中国） の 4 名の講演が行われた。ポスターセッションでは, 31 件, ならびにテクニカルセッションは, 合計 11 セッションあり 72 件の発表が行われた。

会議最終日の 28 日には, テクニカルツアーが行われた。 IFEEC2019 には, 日本人参加者も多く, テクニカルセッ ションの ChairやCo-chair を務めた日本人は 9 人と台湾から の参加者に次いで多かった。

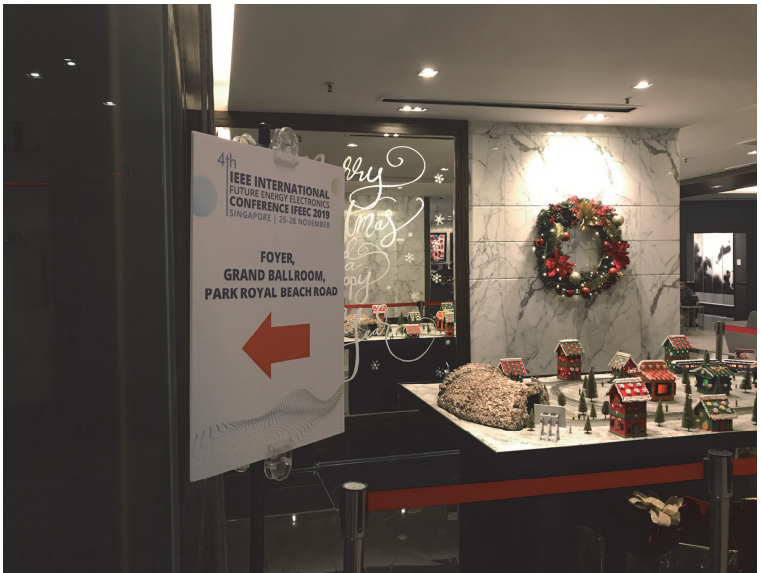

図 1 会場内の案内板

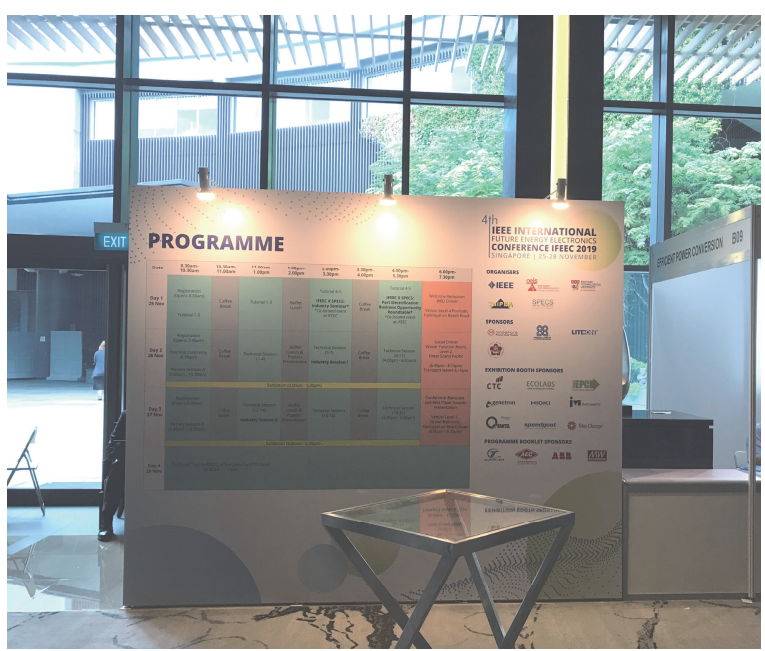

図 2 会場のロビー

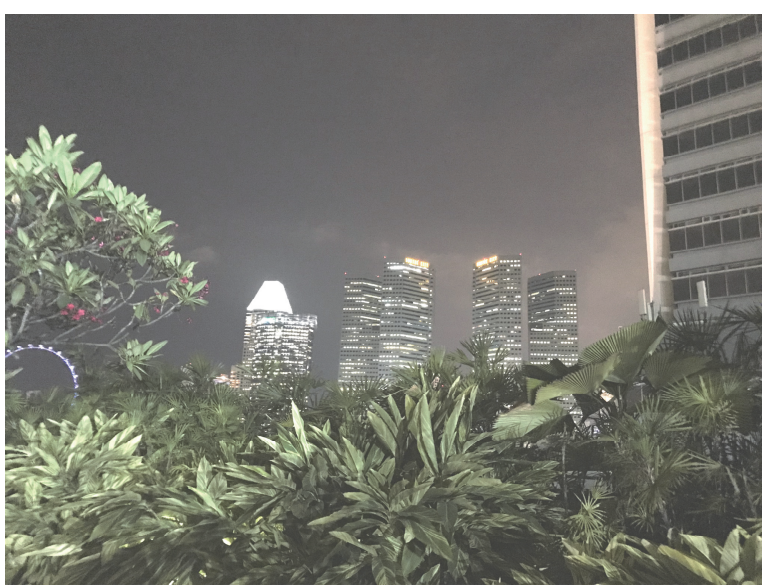

図 3 Welcome Reception 会場（予定）からの夜景

池田 風花（宇部工業高等専門学校） (2020 年 2 月 29 日受付) 